\title{
Determinanty bezpieczeństwa narodowego. Nowe zagrożenia - nowe wyzwania
}

$\mathbf{Z}$ agadnienia poruszane $\mathrm{w}$ niniejszym artykule mają tak długą historię, jak długa jest historia ludzkości, można wręcz stwierdzić, iż bezpieczeństwo jest nieodzownie wpisane w nasze dzieje ${ }^{1}$. Przejawia się bowiem w życiu codziennym, polityce i wielu dyscyplinach naukowych ${ }^{2}$. Pojmowane jako wartość, bywa różnie interpretowane. Rozpatrywane w kontekście warunków (danego stanu rzeczy, stopnia i rodzaju zagrożenia) ukazuje wielkość ocen i różnice interesów. Traktowane jako interes wzbudza szczególne kontrowersje i jako interes żywotny zakłada determinację postaw i działań na rzecz swej realizacji ${ }^{3}$.

Głównym celem tego artykuły jest syntetyczna analiza definicji bezpieczeństwa, jak i charakterystyka jego poszczególnych elementów. Intencjąjest również zaprezentowanie nowych wyznaczników oraz zagrożeń, które wpływają w sposób istotny na sposób pojmowania i ewolucję bezpieczeństwa narodowego.

W klasycznej definicji bezpieczeństwo rozumiane jest jako sytuacja braku zagrożeń dla podstawowych wartości, takich jak przetrwanie, niepodległość oraz integralność terytorialna danego państwa ${ }^{4}$. Z czasem jednak termin ten zaczęto definiować bardziej pozytywnie jako nie tylko pewność utrzymania przez państwo wspomnianych wartości, ale także, co ważniejsze, jako możliwości rozwoju i swobody realizacji własnych interesów w konkretnych warun$\mathrm{kach}^{5}$.

W analizach dotyczących bezpieczeństwa wyodrębnić możemy podstawowy podział na bezpieczeństwo narodowe oraz bezpieczeństwo międzynarodowe. Ponadto termin „,bezpieczeństwo narodowe” używany jest zamiennie z pojęciem „bezpieczeństwo państwa”. Nikłe są szanse na wyeliminowanie jednego z tych terminów, gdyż są one zakorzenione w polskiej

\footnotetext{
${ }^{1}$ Zob. szerzej, R. Rosa, Filozofia bezpieczeństwa, Warszawa 1995.

${ }^{2}$ Szerokość zasięgu pojęciowego bezpieczeństwa podkreśla stanowisko R. Zięby w: Pojęcie i istota bezpieczeństwa państwa w stosunkach międzynarodowych, ,Sprawy Międzynarodowe” 1989, nr 10, s. 50.

3 J. Stańczyk, Bezpieczeństwo narodowe, „Wojsko i Wychowanie” 1996, nr 1, s. 24.

${ }^{4}$ Por. definicję bezpieczeństwa zaprezentowaną przez autorów raportu Sekretarza Generalnego ONZ. M. Grela, Koncepcje bezpieczeństwa - raport Sekretarza Generalnego ONZ, „Sprawy Międzynarodowe” 1986, nr 7-8, s. 116; zob. również J. Świniarski, O naturze bezpieczeństwa. Prolegomena do zagadnień ogólnych, Warszawa-Pruszków 1997, s. 156-165. Skondensowany zbiór definicji zob. m.in. J. Stańczyk, Współczesne pojmowanie bezpieczeństwa, Warszawa 1996 oraz J. Czaputowicz, System czy nieład? Bezpieczeństwo europejskie u progu XXI wieku, Warszawa 1998.

${ }^{5}$ M. Madej, Polska w systemie bezpieczeństwa międzynarodowego, w: Polska w stosunkach międzynarodowych, pod red. S. Bielenia, Warszawa 2007, s. 33. Zob. również klasyfikację wartości podlegających współcześnie ochronie wyszczególnionych przez R. Ziębę w: Leksykon pokoju, Warszawa 1987, s. 29-30 oraz J. Kukułkę w: Bezpieczeństwo a wspótpraca europejska: wspótzależności i sprzeczności interesów, „Sprawy Międzynarodowe” 1982, nr 7, s. 34.

${ }^{6}$ E. Przewodzki, Bezpieczeństwo narodowe. Podstawy wiedzy obywatelskiej, „Wojsko i Wychowanie” 1998, nr 5, s. 39-40.
} 
terminologii i powszechnie stosowane, o czym świadczą chociażby nazwy takich instytucji jak: Biuro Bezpieczeństwa Narodowego, Rada Bezpieczeństwa Narodowego czy chociażby System Obronności Państwa ${ }^{7}$. Bezpieczeństwo państwa i bezpieczeństwo narodowe można również w określonych warunkach zastąpić terminem ogólniejszym, jakim jest bezpieczeństwo Polski ${ }^{8}$.

Pojęcie bezpieczeństwa narodowego stanowi jedną z najstarszych formuł bezpieczeństwa w stosunkach międzynarodowych. Specjaliści z dziedziny stosunków międzynarodowych wywodzą termin bezpieczeństwa narodowego z kategorii egzystencjalnych potrzeb i interesów społeczności ludzkich zorganizowanych w organizacje państwowe ${ }^{9}$. Owe potrzeby i interesy bezpieczeństwa narodu bądź też narodów w przypadku państw wielonarodowych realizowane są przez organy państwowe ${ }^{10}$.

Wśród badaczy wojskowych związanych z Akademią Obrony Narodowej dominują opinie określające bezpieczeństwo narodowe jako zależności zachodzące pomiędzy zagrożeniem a potencjałem obronnym państwa ${ }^{11}$.

Łatwo więc zauważyć, że bezpieczeństwo narodowe jest jednym z etapów ewolucji systemów bezpieczeństwa. Pojawiło się wraz z uformowaniem się narodów jako społeczności o obiektywnie ukształtowanej i społecznie uświadomionej wspólnocie rodowodów oraz celów i warunków istnienia. Jednym z tych warunków były i są nadal zagrożenia o różnym charakterze i różnym stopniu ich nasilenia ${ }^{12}$.

Zjawiskiem wyjściowym dla bezpieczeństwa narodowego są zatem zagrożenia. Ich rodzaje i właściwości wpływają bezpośrednio na charakter i treść bezpieczeństwa narodowego, a także kategorii wobec niego pochodnych ${ }^{13}$. Zagrożenia możemy podzielić na zewnętrzne i wewnętrzne. Zagrożenia zewnętrzne to te, które pochodzą z otoczenia międzynarodowego danego państwa. Natomiast zagrożenia wewnętrzne to te, które mają swoje źródła wewnątrz państwa ${ }^{14}$.

Adekwatnie do podziału zagrożeń możemy też wyróżnić odpowiednio bezpieczeństwo zewnętrzne i wewnętrzne ${ }^{15}$. Pierwsze z nich dotyczy przeciwstawienia się wszelkim zagrożeniom zewnętrznym, a drugie przeciwdziałania zagrożeniom wewnętrznym. Dążenie do za-

\footnotetext{
${ }^{7}$ Słownik terminów z zakresu bezpieczeństwa narodowego, pod red. B. Balcerowicza, Warszawa 2002, s. 169.

${ }^{8}$ R. Szeremietiew, Si vis pacem parabellum. Wewnętrzne i zewnętrzne uwarunkowania bezpieczeństwa międzynarodowego RP, Kraków 2004, s. 16.

${ }^{9}$ Zob. również definicje bezpieczeństwa narodowego: R. Vukadinowić, Międzynarodowe stosunki polityczne, Warszawa 1980, s. 259; M. Berkowitz, P. G. Bock, American National Security. A Reader In Theory and Policy, New York 1965, s. X; A. A. Jordan, W. J. Taylor jr., American National Security. Policy and Process, Baltimore 1981, s. 3-26 cyt. za: W. Fehler, O pojęciu bezpieczeństwa państwa, w: Bezpieczeństwo państw i narodów w procesie integracji europejskiej, pod red. W. Śmiałka, J. Tymanowskiego, Toruń 2002, s. 167; J. J. Romm, Defining national security : the nonmilitary aspect, New York 1993, s. 1-8.

${ }^{10}$ R. Zięba, Kategoria bezpieczeństwa w nauce o stosunkach międzynarodowych, w: Bezpieczeństwo narodowe i międzynarodowe u schytku XX wieku, pod red. E. Haliżak, Warszawa 1997, s. 6.

${ }^{11}$ Zob. W. Stankiewicz, Bezpieczeństwo narodowe a walki niezbrojne, studium, Warszawa 1991, s. 73; C. Rutkowski, Bezpieczeństwo i obronność: strategie - koncepcje - dokumenty, Warszawa 1995, s. 30; Stownik podstawowych terminów dotyczacych bezpieczeństwa, Warszawa 1994, s. 6.

${ }^{12}$ S. Koziej, Bezpieczeństwo narodowe i obronność Rzeczypospolitej Polskiej, Warszawa 1996, s. 6.

${ }^{13}$ S. Koziej, Powinniśmy mieć wspólny język. Podstawowe pojęcia $w$ dziedzinie bezpieczeństwa i obronności, „Polska Zbrojna” 1996, nr 220, s. 10.

${ }^{14}$ Vademecum oficera prasowego, Warszawa 2008, s. 18-19. Zob. definicję zagrożeń w: S. Dworecki, Zagrożenia bezpieczeństwa państwa, Warszawa 2001, s. 61.

${ }^{15}$ Taki podział bezpieczeństwa występuję np. w Konstytucji. Autorzy zajmujący się problematyką bezpieczeństwa podkreślająjednocześnie trudności w rozdzielaniu aspektów wewnętrznych i zewnętrznych, zob. T. Łoś-Nowak, Współczesne stosunki międzynarodowe, Wrocław 1995, s. 135 oraz W. Wołpiuk, Bezpieczeństwo państwa socjalistycznego, w: Państwo i konstytucja: zbiór studiów, pod. red. W. Sokolewicza, Warszawa 1989, s. 117.
} 
pewnienia bezpieczeństwa polega, w tym ujęciu, na tworzeniu optymalnych warunków wewnętrznego bezkonfliktowego progresu istotnych składników danego systemu, jak i eliminowaniu jego ewentualnego zewnętrznego zagrożenia, przez dążenie do takiego ukształtowania otoczenia zewnętrznego, które sprzyjałoby harmonijnemu, symbiotycznemu rozwojowi szerszego podmiotu lub systemu. Reasumując bezpieczeństwo wewnętrzne i zewnętrzne scala się integralnie w ogólne bezpieczeństwo danego państwa ${ }^{16}$.

Inna powszechnie stosowana klasyfikacja zagrożeń dokonywana jest z punktu widzenia ich treści, czyli środków zagrożeń. Mówimy wówczas o zagrożeniu: społecznym, gospodarczym, ekologicznym, informacyjnym, cywilizacyjnym, militarnym, wojennym ${ }^{17}$.

Najgroźniejsze pod względem skali zniszczeń są zagrożenia o charakterze militarnym - wojna nuklearna i wojna konwencjonalna. Jednak prawdopodobieństwo ich wystapienia jednocześnie jest niższe. W następnej kolejności występują zagrożenia z sektora politycznego, takie jak terroryzm i konflikty etniczne, których wystąpienie jest bardziej prawdopodobne, ale mniej destrukcyjne. Natomiast zagrożenia ekonomiczne oraz zagrożenia ekologiczne (degradacja środowiska naturalnego, katastrofy ekologiczne, awarie elektrowni atomowych czy zakładów chemicznych, zanieczyszczenie atmosfery i wody) są bardziej możliwe, ale również relatywnie mniej destrukcyjne. Najbardziej prawdopodobne są jednak zagrożenia w sektorze społeczno-kulturowym, takie jak niekontrolowana migracja, przestępczość zorganizowana, handel narkotykami. Są one zarazem stosunkowo najmniej niszczące ${ }^{18}$.

Komparatystycznie do tego podziału zagrożeń możemy wyodrębnić dziedziny bezpieczeństwa narodowego: społeczną, gospodarczą, ekologiczną, obronną, militarną itd.

Szczególną dziedziną bezpieczeństwa narodowego jest obronność, czyli taka funkcja państwa, która dotyczy przeciwstawienia się wszelkimi posiadanymi zasobami i środkami (militarnymi, niemilitarnymi, wyspecjalizowanymi i ogólnymi) zagrożeniom polityczno-militarnym. Główną i najważniejszą treścią obronności jest przeciwstawienie się zagrożeniom militarnym, ale uzupełnione o jednoczesne przeciwstawienie się również innym zagrożeniom towarzyszącym zagrożeniu militarnemu. Tak więc obronność jest czymś więcej niż tylko kwestią użycia sił zbrojnych. Zajmuje się bowiem użyciem wszystkich sił i środków, jakie państwo posiada do celów obronnych ${ }^{19}$.

W celu realizacji misji tworzenia bezpieczeństwa narodowego nieodzowne są odpowiednie instytucje i struktury bezpieczeństwa, zwane inaczej strukturami realizującymi, bądź systemem bezpieczeństwa narodowego ${ }^{20}$. Istotę owego systemu stanowi cywilna i wojskowa organizacja ochrony i obrony narodowej. Znaczącymi elementami tego systemu są siły zbrojne oraz służby i instytucje rządowe zobowiązane do zapobiegania i przeciwdziałania zagrożeniom zewnętrznym, zapewnienia bezpieczeństwa publicznego, prowadzenia działań ratowniczych oraz ochrony ludności i mienia w sytuacjach nadzwyczajnych, jak również - w zakresie przewidzianym w Konstytucji RP i właściwych ustawach - władze samorządowe ${ }^{21}$ oraz inne podmioty prawne, w tym przedsiębiorcy tworzący potencjał przemysłowo-obronny ${ }^{22}$.

\footnotetext{
${ }^{16}$ J. Kaczmarek, Problemy bezpieczeństwa RP, „Myśl Wojskowa” 1991, nr 1, s. 14.

${ }^{17}$ S. Koziej, Bezpieczeństwo..., s. 7.

18 J. Czaputowicz, Bezpieczeństwo w teoriach stosunków międzynarodowych, w: Bezpieczeństwo międzynarodowe. Teoria i praktyka, pod red. K. Żukrowskiej, M. Grącik, Warszawa 2006, s. 75.

${ }^{19}$ S. Koziej, Powinniśmy..., s. 10.

${ }^{20}$ Zob. Strategia Bezpieczeństwa Narodowego Rzeczypospolitej Polskiej, Warszawa 1997.

${ }^{21}$ Zob. m.in. A. Mączyński, O potrzebie i możliwości właczenia terenowych organów administracji oraz samorzadów terytorialnych w system bezpieczeństwa narodowego, „Myśl Wojskowa” 1998, nr 3, s. 10-21.

22 J. Marczak, op. cit., s. 22.
} 
Warto również podkreślić, że zarówno bezpieczeństwo narodowe jako całość, jak i wszystkie jego dziedziny, w tym także obronność, mają swoją strategię (zawierającą ogólne zasady i myśl przewodnią postępowania podmiotu w dziedzinie bezpieczeństwa), politykę (odnoszącą się do konkretnych działań w ramach całej strategii postępowania podmiotu w dziedzinie bezpieczeństwa) i doktrynę (określającą zasady funkcjonowania poszczególnych elementów systemów bezpieczeństwa). Dopiero uwzględnienie tych wszystkich elementów pozwala analizować bezpieczeństwo jako proces ciagły, w ramach którego państwa starają się doskonalić instrumenty i metody zapewniające im poczucie pewności istnienia, posiadania i rozwoju.

Z historycznego punktu widzenia niemal od starożytności do XIX wieku podstawową treścią zmagań wojennych była bezpośrednia walka człowieka z człowiekiem, przy użyciu prostych narzędzi walki. Sytuacja zmieniła się dopiero w okresie pojawienia się armii masowych, opartych na powszechnym poborze i zaopatrzonych w wielką ilość efektywnych i o większej sile rażenia środków walki. W okresie I i II wojny światowej obserwujemy absolutyzowanie płaszczyzny wojskowo-politycznej ${ }^{23}$ oraz prawnej bezpieczeństwa narodowego ${ }^{24}$.

Z kolei następstwa i doświadczenia II wojny światowej spowodowały, że w okresie zimnej wojny bezpieczeństwo odnoszono przede wszystkim do ochrony granic, a więc zapewnienia bytu i istnienia państwa. Dopiero rozwój techniki, szczególnie tej militarnej, postęp cywilizacyjny, upadek muru berlińskiego i wyjście z impasu zimnej wojny w sferę rozszerzającej się współpracy otworzyły nowe perspektywy w stosunkach między państwami. Miało to wpływ na pojęcie i rozumienie bezpieczeństwa. Coraz częściej dostrzegano wpływ czynników społecznych, gospodarczych czy ekologicznych na funkcjonowanie państwa, a zatem także na jego bezpieczeństwo ${ }^{25}$.

Przełom XX i XXI wieku przyniósł zasadnicze zmiany w kwestii pojęcia, postrzegania i określania bezpieczeństwa narodowego. Współcześnie można zaobserwować tendencję do przedmiotowego poszerzania bezpieczeństwa narodowego ${ }^{26}$ o nowe płaszczyzny: ekonomiczną, naukowo-techniczną, ideologiczną, kulturową, społeczną i ekologiczną (przykładem jest chociażby „Koncepcja Strategiczna Sojuszu” z 1999 roku) ${ }^{27}$.

Istota szerokiego postrzegania bezpieczeństwa narodowego sprowadza się do tworzenia warunków zapewnienia pomyślności narodów oraz zagwarantowania swobód rozwojowych. Stanowi to wyraz postępu rozwoju cywilizacyjnego narodów oraz dążenie do życia w dobrobycie $^{28}$.

Jednocześnie z poszerzeniem zakresu przedmiotowego można zauważyć tendencję do przestrzennego (terytorialnego) poszerzania bezpieczeństwa państwa ${ }^{29}$. Okoliczność ta oznacza, że na poziom bezpieczeństwa jednostek, społeczności lokalnych i narodów coraz czę-

\footnotetext{
${ }^{23}$ Bardzo wyraziste ujęcie tego stanowiska odnaleźć można w pracy B. Winiarskiego Bezpieczeństwo, arbitraż, rozbrojenie, Poznań 1927, s. 1.

${ }^{24}$ J. Marczak, Bezpieczeństwo narodowe - pojęcie, charakter, uwarunkowania, w: Bezpieczeństwo narodowe Polski w XXI wieku. Wyzwania i strategie, pod red. R. Jakubczaka, J. Flisa, Warszawa 2006 s. 18.

${ }^{25}$ M. Kulisz, Terminologiczne ujęcie bezpieczeństwa narodowego, „Kwartalnik Bellona” 2008, nr 4, s. 18.

${ }^{26} \mathrm{~W}$ wymiarze przedmiotowym bezpieczeństwo jest pewnością niezbędnych warunków rozwoju i aktywności. Cyt. za: J. Kukułka, Bezpieczeństwo międzynarodowe w Europie środkowej po zimnej wojnie, Warszawa 1994, s. 41.

27 A. D. Rotfeld, Bezpieczeństwo Polski a bezpieczeństwo Europy, w: Międzynarodowe czynniki bezpieczeństwa Polski, pod red. A. D. Rotfelda, Warszawa 1986, s. 15-18.

${ }^{28}$ J. Marczak, op. cit., s. 19.

${ }^{29}$ Zob. między innymi R. Zięba, Instytucjonalizacja bezpieczeństwa europejskiego. Koncepcje-struktury-funkcjonowanie, Warszawa 2004, s. 43-44.
} 
ściej wpływają wydarzenia nie tylko w ich najbliższym otoczeniu, ale także w regionie, na kontynencie, a nawet na całym globie ${ }^{30}$.

Tendencje do poszerzania zakresu przedmiotowego i przestrzennego bezpieczeństwa państwa w stosunkach międzynarodowych są rezultatem dokonujących się procesów internacjonalizacji różnych dziedzin życia społecznego (gospodarki, kultury, polityki itd.) i będącego jej odbiciem wzrostu korelacji międzynarodowej. Zjawiska te rodzą nowe wyzwania i zagrożenia dla bezpieczeństwa narodowego, a także stwarzają nowe, większe możliwości postrzegania tych zagrożeń i skutecznego ich eliminowania ${ }^{31}$.

We współczesnym świecie istnieje kilka możliwości zagwarantowania bezpieczeństwa narodowego. Pierwsza, poprzez przedsięwzięcia unilateralne, realizowane przez działania jednostronne (np. hegemonizm mocarstwowy, izolacjonizm, polityka neutralności, niezaangażowanie), system równowagi sił (przybierający różne odmiany od koncertu mocarstw po system bipolarny i system równowagi strachu), system blokowy (obejmujący sojusze), system bezpieczeństwa kooperacyjnego oraz system bezpieczeństwa zbiorowego (regionalnego lub uniwersalnego $)^{32}$.

Jeśli państwo zamierza zapewnić sobie obronność wstępując do koalicji państw, to musi w pewnym stopniu zrezygnować ze swojej autonomii. Z kolei państwo takie jak Rzeczypospolita Polska, ze względu na swoje położenie geostrategiczne i geopolityczne, nie może gwarantować sobie bezpieczeństwa samodzielnie, nawet po ogłoszeniu neutralności. Składa się na to szereg uwarunkowań takich jak chociażby położenie pomiędzy dwoma mocarstwami ${ }^{33}$.

$\mathrm{Na}$ bezpieczeństwo narodowe państw oddziaływają przede wszystkim procesy i zjawiska w ich otoczeniu - w regionie, w Europie i w ramach wspólnoty euroatlantyckiej. Znaczący wpływ ma także dynamika stosunków w Sojuszu Północnoatlantyckim i Unii Europejskiej. Członkostwo w tych strukturach stwarza warunki sprzyjające rozwojowi gospodarczemu i postępowi cywilizacyjnemu, tym samym przyczyniając się do zwiększenia bezpieczeństwa państwa $^{34}$.

O ile dawniej największym zagrożeniem dla świata były silne państwa, które kierowały się ideologią i polityką agresji, to dzisiaj źródłem zagrożeń są podmioty pozapaństwowe, często trudne do zidentyfikowania oraz nierozwiązane konflikty regionalne i lokalne ${ }^{35}$, które są katalizatorami napięć obejmujących swym zasięgiem rozległe obszary. Niebezpieczeństwo stanowią także państwa upadłe (failed states), takie jak Irak, Afganistan, Czad, Sudan, które nie są w stanie ani kontrolować swego terytorium, ani wykonywać skutecznie władzy ${ }^{36}$. Struktury przestępcze takie jak Al-Kaida uzyskują schronienie na terytoriach tych państw, tworząc tam swoje ośrodki szkoleniowe i centra dowodzenia. Wsparcia natomiast udzielają im państwa o systemach autokratycznych, nieobliczalnych, zainteresowanych destabilizacją w świecie. Wszystko to sprzyja powstawaniu i rozwojowi różnego rodzaju międzynarodowych związków przestępczych, które później dokonują aktów zbrodni wobec innych państw ${ }^{37}$. Obecność

\footnotetext{
${ }^{30}$ J. Stefanowicz, Bezpieczeństwo współczesnych państw, Warszawa 1984, s. 14.

${ }^{31}$ R. Zięba, Kategoria..., s. 15-16.

32 J. Barcik, Europejska Polityka Bezpieczeństwa i Obrony. Aspekty prawne i polityczne, Bydgoszcz-Katowice 2008, s. 23.

33 J. Kaczmarek, Problemy..., s. 15.

${ }^{34}$ Vademecum..., op. cit., s. 15.

${ }^{35}$ Np. w Kaszmirze, w regionie Wielkich Jezior oraz na Półwyspie Koreańskim.

${ }^{36}$ Wg raportu opublikowanego przez Foreign Policy w 2008 roku ich liczbę szacuje się na blisko sześćdziesiąt.

${ }^{37}$ C. Lusiński, Globalne i narodowe środowisko bezpieczeństwa a przyszłe operacje z udziałem sił zbrojnych RP, „Zeszyty Naukowe AON” 2008, nr 2A, s. 22.
} 
sił militarnych wielu państw, w tym również Polski, w misjach pokojowych oraz operacjach stabilizacyjnych ułatwia uporządkowanie spraw wewnętrznych i lokalnych w tych państwach i rejonach.

Nieustannie ulega powiększeniu również dystans rozwojowy pomiędzy poszczególnymi regionami świata, co powoduje wzrost napięć w stosunkach międzynarodowych. Tym niesprzyjającym tendencjom towarzyszy narastanie poczucia współodpowiedzialności za losy świata oraz przeświadczenie, że walka z zagrożeniami i wyzwaniami wymaga wspólnych działań. Bowiem żadne z państw nie jest wystarczająco silne by móc samodzielnie pokonywać współczesne zagrożenia ${ }^{38}$.

Zaprezentowane $\mathrm{w}$ niniejszym artykule zagadnienia związane $\mathrm{z}$ bezpieczeństwem narodowym poruszają jedynie wybrane aspekty problemu oraz kwestie zmiany w czasie pojęć. W literaturze brak jest zgody co do jednych akceptowalnych przez wszystkich definicji oraz determinantów bezpieczeństwa narodowego. Można jedynie wyodrębnić pewne elementy, które są dla wszystkich autorów wspólne. Przeprowadzona analiza dowodzi, że współcześnie treść bezpieczeństwa narodowego opiera się na pewności realizacji żywotnych interesów, jak też obiektywnych warunków ich poszanowania z zewnątrz. Zagrożenie w jednym państwie jest w dzisiejszym świecie jednocześnie zagrożeniem dla wielu państw (tzw. efekt domina). Wobec czego dostrzec można rosnącą współzależność państw w zakresie kształtowania swego bezpieczeństwa narodowego ${ }^{39}$. Prezentowany artykuł nie jest wyczerpującą kwerendą opisywanego problemu, zwraca natomiast uwagę na zmiany wywołane dostosowywaniem systemu bezpieczeństwa narodowego do nowych wyzwań i zagrożeń, które współcześnie charakteryzują się nieprzewidywalnością i niepewnością.

\section{Summary}

This paper analyzes the definitions and characterizes the elements related to national security. The author pays particular attention to the change of determinants and threats which significantly influence the way in which a given state's security is perceived, and how it evolves. In the author's opinion, at present one can observe the tendency to expand the subject matter and spatial range of national security in international relations, which follows from the internationalization of various realms of social life. It is impossible to improve the national security of a given state while tolerating the disturbances of peace that result from the widening gaps between different parts of the world, or unsolved regional and local conflicts. The main purpose of this paper is to draw the reader's attention to the changes resulting from the need to adjust the national security system to the new challenges; the changes that not only aim to defy these challenges, but also to prevent the factors that generate them.

${ }^{38}$ Zob. European Security Strategy, A Secure Europe in a Better World, Brussels, 12 December 2003.

39 A. Dawidczyk, Nowe wyzwania, zagrożenia i szanse dla bezpieczeństwa Polski u progu XXI wieku, Warszawa 2001, s. 19. Zob. także M. Pietraś, Bezpieczeństwo państwa w późnowestfalskim środowisku międzynarodowym, w: Kryteria bezpieczeństwa międzynarodowego państwa, pod red. S. Dębski, B. Górka-Winter, Warszawa 2003, s. 161; R. Stemplowski, Horyzont poznawczy i polityczny pojęcia ,, bezpieczeństwo państwa”, w: Bezpieczeństwo międzynarodowe czasu przemian. Zagrożenia - koncepcje - instytucje, pod red. R. Kuźniara, Z. Lachowski, Warszawa 2003, s. 257. 